Article

LANGARO, A.C. ${ }^{* *}$

AGOSTINETTO, D. ${ }^{1}$

OLIVEIRA, C. ${ }^{1}$

FRANCO, J.J. ${ }^{1}$

ZANDONÁ, R.R. ${ }^{1}$

VARGAS, L. ${ }^{2}$

\section{Influence of Nitrogen Fertilization on HeRbicide SELECTIVITY IN RICE}

\section{Influência da Adubação Nitrogenada na Seletividade de Herbicidas ao Arroz}

* Corresponding author:
<langaro.ac@gmail.com>

Received: May 17, 2017

Approved: May 18, 2018

\section{Planta Daninha 2018; v36:e018180161}

Copyright: This is an open-access article distributed under the terms of the Creative Commons Attribution License, which permits unrestricted use, distribution, and reproduction in any medium, provided that the original author and source are credited.
ABSTRACT - Chemical weed control and nitrogen fertilization are common practices in irrigated rice crops. Nitrogen is an essential element for growth and development of plants and may influence herbicide selectivity. In this study, herbicide selectivity was evaluated according to nitrogen application time in irrigated rice crops. The experiment was conducted in the field in a split-plot design with four replications. Treatments were arranged in a factorial scheme: factor A consisted of different nitrogen application times (without nitrogen, all nitrogen applied before flooding, half of the nitrogen rate applied before flooding and the other half after flooding, all nitrogen applied after flooding); factor B consisted of the application of the herbicides quinclorac, bentazon, bispyribac-sodium and carfentrazone-ethyl. Nitrogen application increased plant height and dry matter accumulation in rice plants, while nitrogen application before flooding and split $\mathrm{N}$ applications were favorable to the crop. The herbicide bispyribac-sodium causes the greatest injury and the greatest reduction in rice plant height, followed by bentazon and carfentrazone-ethyl, while the lowest injury and the highest grain yield were caused by the application of quinclorac.

Keywords: Oryza sativa, nitrogen, selectivity, weeds.

RESUMO - O controle químico de plantas daninhas e a adubação nitrogenada são práticas comuns na cultura do arroz irrigado. O nitrogênio é elemento essencial no crescimento e desenvolvimento das plantas, podendo influenciar na seletividade dos herbicidas. Neste estudo, avaliou-se a seletividade de herbicidas em função da época de aplicação de nitrogênio na cultura do arroz irrigado. O experimento foi conduzido em campo, em delineamento em parcelas subdivididas com quatro repetições. Os tratamentos foram arranjados em esquema fatorial, sendo o fator $A$ constituído por diferentes épocas de aplicação de nitrogênio (sem nitrogênio; todo o nitrogênio aplicado antes da entrada de água; metade do nitrogênio aplicada antes da entrada de água e outra metade depois; e todo o nitrogênio aplicado depois da entrada da água) e o fator $B$, pela aplicação dos herbicidas quinclorac, bentazon, bispyribac-sodium e carfentrazone-ethyl. A aplicação de nitrogênio resulta em maior estatura e acúmulo de matéria seca nas plantas de arroz, e a aplicação desse nutriente antes da entrada da água e o parcelamento dele favorecem a cultura. O herbicida bispyribac-sodium resulta em maior fitotoxicidade e redução da estatura das plantas de arroz, seguido por bentazon e carfentrazone-ethyl, enquanto a menor fitotoxicidade e a maior produtividade de grãos são decorrentes da aplicação de quinclorac.

Palavras-chave: Oryza sativa, nitrogênio, seletividade, plantas daninhas.

1 Universidade Federal de Pelotas, Pelotas-RS, Brasil. ${ }^{2}$ Embrapa Trigo, Passo Fundo, Rio Grande do Sul, Brasil. 


\section{INTRODUCTION}

Rice is considered to be the most economically important product in many developing countries (Duan et al., 2007). With the growing increase in consumption, influenced by population growth, the productive sector is supposed to seek new techniques that can increase production (FAO, 2015).

Among problems commonly found in crop management, weed interference may cause an $80-90 \%$ yield reduction of irrigated rice grains (Andres and Machado, 2004). However, these losses can range from 4 to $30 \%$ according to genotype, flooding times, plant arrangement used in the crop and herbicide doses in use (Galon et al., 2007; Pinto et al., 2008). In order to avoid losses resulting from competition against weeds, several phytosanitary treatments are used, and chemical control is the main tool to control weeds in irrigated rice fields (Concenço et al., 2006). Another practice that interferes with crop-weed interactions is nitrogen fertilization because it is crucial to plant growth. In addition, it may accelerate plant recovery under the toxic effects of herbicides (Mariot et al., 2003).

Nitrogen $(\mathrm{N})$ is an essential nutrient for all plant species, as it is a key component of several organic compounds, such as chlorophylls, cytochromes, enzymes and coenzymes (Campestrini et al., 2014), which participate in photosynthesis (Taylaran et al., 2011) as well as in dry matter production and accumulation (Feng et al., 2009) and rice panicle formation (Wang et al., 2012; Zhang et al., 2013). It is known that $\mathrm{N}$ fertilization is one of the best ways to ensure rice crop productivity (Wang et al., 2012; Zhang et al., 2013). N helps increase the leaf area of rice plants; as a result, intercepted solar radiation and photosynthetic rate become more efficient, thus improving grain yield (Fageria et al., 2003). However, after application, this nutrient can suffer several transformations, and some of them result in losses, mainly by denitrification and volatilization processes (Vahl and Souza, 2004).

$\mathrm{N}$ application times are predetermined in two dressings, with half the dose preceding or at the beginning of tillering, at stage $\mathrm{V}_{3} / \mathrm{V}_{4}$. The other half should be applied during panicle differentiation (RO stage); that way, it will provide optimal N supply of in the critical stage (SOSBAI, 2012). The combination of appropriate doses and times not only reduces production costs and environmental pollution, but also results in better performance of irrigated rice, which increases grain yield (Fageria et al., 2011). Thus, the management of nitrogen fertilization, according to application times, can alter the photosynthetic performance of plants during grain filling, thereby affecting the duration and rate of dry matter accumulation (Camargo et al., 2011).

Fertilization timing may influence the behavior of rice plants, because one of the selectivity strategies of herbicides is their lower translocation, as compared to that of weeds (Oliveira Jr. et al., 2011). However, $\mathrm{N}$ supply before herbicide application may lead to increased translocation and crop injuries. Therefore, the objective of this study was to evaluate herbicide selectivity according to nitrogen application time in irrigated rice crops.

\section{MATERIAL AND METHODS}

The experiment was conducted on the field, using a split-plot design in with four replications; each experimental unit consisted of a subplot with usable area of $6.12 \mathrm{~m}^{2}(4 \times 1.53 \mathrm{~m})$.

The area was prepared according to the conventional rice cultivation system; sowing was carried out on October $31^{\text {st }}$, 2013, using the Puitá INTA CL cultivar at a density of $120 \mathrm{~kg} \mathrm{ha}^{-1}$. Fertilization was performed by using $300 \mathrm{~kg} \mathrm{ha}^{-1}$ of fertilizer with a 2-20-20 formulation. The plots consisted of nitrogen application times (without nitrogen, all nitrogen applied before flooding, half of the nitrogen applied before flooding and another half after flooding, and all nitrogen applied after flooding); the amount of nitrogen was $120 \mathrm{~kg}$ ha, which was calculated according to the soil analysis. Flood irrigation was performed at 22 days after crop emergence (DAE), when plants were at the V4 stage, at two days after herbicide application and one day after $\mathrm{N}$ application. The application of $100 \%$ nitrogen after flooding was performed three days after the beginning of flood irrigation. The subplots were composed of the herbicides quinclorac ( $375 \mathrm{~g}$ a.i. ha $\mathrm{a}^{-1}$ ), bentazon (960 g a.i. ha $\mathrm{a}^{-1}$ ), bispyribac-sodium (50 g a.i. ha ${ }^{-1}$ ) and carfentrazone-ethyl (200 g a.i. ha $\left.{ }^{-1}\right)$, in addition to a control treatment with application of cyhalofop-butyl (315 g a.i. ha ${ }^{-1}$ ). The herbicides 
were applied at $20 \mathrm{DAE}$; the main weeds in the area were barnyard grass (Echinochloa spp.) and cyperaceae (Cyperus iria and Cyperus esculentus). During panicle differentiation, an additional nitrogen application of $30 \mathrm{~kg}$ per hectare was performed throughout the experiment, also with the treatments without $\mathrm{N}$.

Spraying was performed early in the morning, using a $\mathrm{CO}_{2}$-powered continuous-pressure sprayer and a bar with four Teejet 110.015 fan-type nozzles, spaced at $0.5 \mathrm{~m}$, with spraying volume of $120 \mathrm{~L} \mathrm{ha}^{-1}$. At the time of application, the meteorological conditions were adequate, with relative humidity of $72 \%$ and temperature of $21{ }^{\circ} \mathrm{C}$. In order to maintain a weed-free area, cyhalofop-butyl was applied on the total area two days after the herbicides had been applied because a great population of barnyard grass was found.

The evaluated field variables were plant height, shoot dry matter and injury, at 10, 20 and 30 days after the application of the treatments (DAT). At 30 DAT, the number of tillers per plant was also evaluated by manually counting the number of plants and tillers per meter.

In order to determine height, 10 plants per experimental unit were measured. For assessment of injury, visual scores were assigned on a percentage scale, where $0 \%$ means no effect and $100 \%$ represents the complete death of plants (Frans et al., 1986).

Before the harvest, 10 panicles were collected from the usable area of each experimental unit, in order to determine the number of full and empty grains per panicle. Each panicle was threshed manually, and the full and sterile grains per panicle were counted. Grain yield of rice was determined by harvesting the usable area of plots when moisture content was approximately $22 \%$. Afterwards, the grains were weighed and humidity was determined, data were corrected to $13 \%$ moisture. Productivity was expressed in $\mathrm{kg} \mathrm{ha}^{-1}$. Thousand grain weight was quantified by manually counting eight samples containing 100 grains; the value was corrected to one thousand grains and expressed as grams.

Data were analyzed for homoscedasticity and were subsequently submitted to analysis of variance $(p \leq 0.05)$. In case of statistical significance, the comparison of means was performed by Duncan's test $(\mathrm{p} \leq 0.05)$.

\section{RESULTS AND DISCUSSION}

There was an interaction between herbicides and nitrogen application time for the height and injury variables at 10 DAT (Tables 1 and 4). There was a simple effect of herbicides on height (20 DAT), injury (20 and 30 DAT) and grain yield (Tables 2, 5 and 8$)$. For the variables height (20 and 30 DAT), shoot dry matter (10, 20 and 30 DAT), number of tillers per plant, number of empty grains, thousand grain weight and grain yield, there was a simple effect of nitrogen application time (Tables 3, 6, 7 and 9). For the variable number of grains per panicle, there was no statistical significance (data not shown).

When the effects of the herbicides were compared, the greatest reduction in rice plant height was usually found when bispyribac-sodium was applied, and this effect was found mainly when all nitrogen was applied before flooding (Table 1). At the same time, the application of bentazon and carfentrazone-ethyl also reduced rice plant height.

Bispyribac-sodium is an inhibitor of the acetolactate synthase enzyme, resulting in a reduction in the branched chain amino acid synthesis, such as valine, leucine and isoleucine (Roman, 2007). The phytotoxic effect characterized by chlorosis is typical of herbicides with a physiological action, that is, products with good translocation and that interfere directly in the metabolism of plants, as is the case of bispyribac-sodium (Rodrigues and Almeida, 2011), often resulting in a reduction of plant height.

When nitrogen application times were compared, the greatest height reduction was found for treatments without nitrogen or when all nitrogen was applied after flooding. The smallest plant height in treatments where $100 \% \mathrm{~N}$ was applied after flooding may be due to nutrient losses. When urea is directly applied to water, it is more susceptible to losses caused by ammonium volatilization and denitrification (Humphreys et al., 1987). As a result, a small amount of urea is available to plants, which reduces their height. 
Table 1 - Height $(\mathrm{cm})$ at 10 days after application of herbicides (DAT) to rice plants which received the application of postemergence herbicides and according to nitrogen application time

\begin{tabular}{|l|c|c|c|c|}
\hline \multirow{2}{*}{\multicolumn{1}{c|}{ Herbicide }} & \multicolumn{4}{|c|}{ Neight (cm) } \\
\cline { 2 - 5 } & \multicolumn{3}{|c|}{ Nitrogen application time } \\
\cline { 2 - 5 } & Without N & Before water & $\begin{array}{c}\text { Half before/ } \\
\text { Half after }\end{array}$ & After water \\
\hline Nontreated & $28.2 \mathrm{~B} \mathrm{a}$ & $35.7 \mathrm{~A} \mathrm{a}$ & $35.5 \mathrm{~A} \mathrm{a}$ & $27.0 \mathrm{~B} \mathrm{~b}$ \\
\hline Quinclorac & $30.7 \mathrm{~B} \mathrm{a}$ & $37.7 \mathrm{~A} \mathrm{a}$ & $35.5 \mathrm{~A} \mathrm{a}$ & $30.7 \mathrm{~B} \mathrm{a}$ \\
\hline Bentazon & $29.3 \mathrm{BC} \mathrm{a}$ & $32.9 \mathrm{AB} \mathrm{b}$ & $35.6 \mathrm{~A} \mathrm{a}$ & $28.0 \mathrm{C} \mathrm{ab}$ \\
\hline Bispyribac-sodium & $25.8 \mathrm{~B} \mathrm{a}$ & $29.9 \mathrm{~A} \mathrm{c}$ & $31.3 \mathrm{~A} \mathrm{~b}$ & $25.8 \mathrm{~B} \mathrm{~b}$ \\
\hline Carfentrazone-ethyl & $27.9 \mathrm{~B} \mathrm{a}$ & $32.6 \mathrm{~A} \mathrm{~b}$ & $32.6 \mathrm{~A} \mathrm{ab}$ & $28.8 \mathrm{~B} \mathrm{ab}$ \\
\hline
\end{tabular}

Means followed by lowercase letters in the column differ the herbicides and those followed by capital letters on the line differ the nitrogen application time by Duncan's test $(\mathrm{p} \leq 0.05)$.

At 20 DAT, the rice plants had the lowest height when the plants received the application of bispyribac-sodium and carfentrazone-ethyl; however, they did not differ from the nontreated plants (Table 2). This reduction was also caused by the physiological effect of the herbicide, i.e., growth reduction, as aforementioned. Similar results were found when bispyribac-sodium was applied on upland rice crops at 7 and 14 DAT, causing height reduction (Petter et al., 2011).

When the effect of $\mathrm{N}$ application time was evaluated, there was a reduction in plant height in the nitrogen-free treatment at 20 and 30 DAT (Table 3). Among treatments with N, during both evaluation times, there was height reduction when all nitrogen was applied after flooding. Thus, it is evident that, considering the variable plant height, the best nitrogen application time is before flooding, possibly because losses by volatilization and denitrification were smaller.

Table 2 - Height (cm) at 20 days after the application of treatments (DAT) to rice plants which received the application of post-emergent herbicides

\begin{tabular}{|l|c|}
\hline \multicolumn{1}{|c|}{ Herbicide } & Height $(\mathrm{cm})$ \\
\hline Nontreated & $41.8 \mathrm{ab}$ \\
\hline Quinclorac & $45.4 \mathrm{a}$ \\
\hline Bentazon & $43.3 \mathrm{ab}$ \\
\hline Bispyribac-sodium & $40.4 \mathrm{~b}$ \\
\hline Carfentrazone-ethyl & $40.8 \mathrm{~b}$ \\
\hline CV $(\%)$ & 12.13 \\
\hline
\end{tabular}

Means followed by different letters in the column differ by Duncan's test $(\mathrm{p} \leq 0.05)$.
Table 3 - Height at 20 and 30 days after the application of treatments (DAT) to rice plants according to nitrogen application time

\begin{tabular}{|l|c|c|}
\hline \multirow{2}{*}{ Nitrogen application time } & \multicolumn{2}{|c|}{ Height $(\mathrm{cm})$} \\
\cline { 2 - 3 } & 20 DAT & 30 DAT \\
\hline Without N & $37.1 \mathrm{c}$ & $42.9 \mathrm{~d}$ \\
\hline Before water & $45.8 \mathrm{a}$ & $58.7 \mathrm{a}$ \\
\hline Half before/Half after & $44.6 \mathrm{a}$ & $53.2 \mathrm{~b}$ \\
\hline After water & $41.9 \mathrm{~b}$ & $47.3 \mathrm{c}$ \\
\hline CV $(\%)$ & 9.96 & 9.96 \\
\hline
\end{tabular}

Means followed by distinct letters in the column differ by Duncan's test $(\mathrm{p} \leq 0.05)$.

As for the variable injury, it was found that all herbicide treatments presented phytotoxic effects, when compared to the nontreated plants (Table 4). Among the herbicides, the greatest injury was found when bispyribac-sodium was applied at all nitrogen application times, but it did not differ from carfentrazone-ethyl when $\mathrm{N}$ was fractionated or applied after flooding. When comparing $\mathrm{N}$ application times, there was lower bentazon injury when $100 \% \mathrm{~N}$ was applied before flooding or when $50 \%$ was applied before and $50 \%$ was applied after flooding. The application of bispyribac-sodium caused the highest injury when all nitrogen was applied before flooding. In comparison to the other herbicides, nitrogen application time caused no difference in symptoms.

Thus, it can be inferred that $\mathrm{N}$ application before flooding favors the recovery from injury caused by bentazon to rice plants. When the application of bispyribac-sodium was evaluated, there was an inverse behavior, that is, nitrogen application before flooding resulted in greater injury. A possible explanation for this result is the fact that bispyribac-sodium is a systemic herbicide, and its translocation can be increased according to nitrogen absorption. However, it cannot be stated that this was the mechanism which caused greater injuries. 
Table 4 - Injury (\%) at 10 days after the application of treatments (DAT) to rice plants which received the application of postemergent herbicides and according to nitrogen application time

\begin{tabular}{|l|c|c|c|c|}
\hline \multirow{2}{*}{ Herbicide } & \multicolumn{4}{|c|}{ Injury (\%) } \\
\cline { 2 - 5 } & \multicolumn{3}{|c|}{ Nitrogen application time } \\
\cline { 2 - 5 } & Without N & Before water & $\begin{array}{c}\text { Half before/ } \\
\text { Half after }\end{array}$ & After water \\
\hline Nontreated & $0 \mathrm{~A} \mathrm{c}$ & $0 \mathrm{~A} \mathrm{~d}$ & $0 \mathrm{~A} \mathrm{~d}$ & $0 \mathrm{~A} \mathrm{~d}$ \\
\hline Quinclorac & $6.3 \mathrm{~A} \mathrm{~b}$ & $4.5 \mathrm{~A} \mathrm{c}$ & $4.3 \mathrm{~A} \mathrm{bc}$ & $4.3 \mathrm{~A} \mathrm{c}$ \\
\hline Bentazon & $5.0 \mathrm{AB} \mathrm{b}$ & $3.5 \mathrm{~B} \mathrm{c}$ & $3.5 \mathrm{~B} \mathrm{c}$ & $7.8 \mathrm{~A} \mathrm{~b}$ \\
\hline Bispyribac-sodium & $8.5 \mathrm{~B} \mathrm{a}$ & $12.5 \mathrm{~A} \mathrm{a}$ & $8.3 \mathrm{~B} \mathrm{a}$ & $7.3 \mathrm{~A} \mathrm{a}$ \\
\hline Carfentrazone-ethyl & $6.0 \mathrm{~A} \mathrm{~b}$ & $7.5 \mathrm{~A} \mathrm{~b}$ & $6.5 \mathrm{~A} \mathrm{ab}$ & \\
\hline
\end{tabular}

Means followed by lowercase letters in the column differ for herbicides and those followed by capital letters in the row differ for nitrogen application times by Duncan's test $(\mathrm{p} \leq 0.05)$.

At 20 DAT, there was higher injury in the crop, resulting from the application of bispyribacsodium, followed by quinclorac and carfentrazone-ethyl (Table 5). The lowest injury was found with bentazon, which did not differ from the nontreated plants control treatment and was more selective to rice. After evaluation of the effect of herbicides at $30 \mathrm{DAT}$, it was found that only bispyribac-sodium resulted in injury to the crop. This finding highlights the recovery of plants that were treated with other herbicides. However, the evolution of injury symptoms until the apparent full recovery of plants can still result in reductions in the final yield of the crop because of non-perceptible metabolic disturbances.

In all evaluation times, the highest dry matter increase was found when $\mathrm{N}$ was applied before flooding, except at 10 DAT, when there was no difference for split applications of this nutrient (Table 6). The losses resulting from the application of urea in water determined less efficiency with this procedure. These results are in agreement with those found by Humphreys et al. (1987), who also found greater efficiency with the application of urea before the flood, resulting in greater dry matter accumulation.

Average efficiency of $\mathrm{N}$ utilization is relatively low in irrigated rice fields, around $40 \% \mathrm{Xu}$ et al., 2012). As a result of high consumption of nitrogen fertilizers with low efficiency, a substantial amount of fertilization is lost, causing a series of environmental problems (Xuejun and Fusuo, 2011). N excess is rapidly lost as a result of ammonia volatilization, denitrification, surface runoff and leaching (Wang et al., 2012). Based on the results of dry matter accumulation according to nitrogen application time, it was found that when $100 \%$ of nitrogen fertilization is applied before flooding, losses are smaller.

Regardless of nitrogen application time, it was found that there is always a gain in dry matter accumulation, compared to the control treatment without $\mathrm{N}$, and there was a $227 \%$ increase in dry matter accumulation when $100 \% \mathrm{~N}$ was applied before flooding, $135 \%$ when $\mathrm{N}$

Table 5 - Injury at 20 and 30 days after the application of treatments (DAT) to rice plants which received the application of post-emergent herbicides

\begin{tabular}{|l|c|c|}
\hline \multirow{2}{*}{\multicolumn{1}{|c|}{ Herbicide }} & \multicolumn{2}{c|}{ Injury (\%) } \\
\cline { 2 - 3 } & 20 DAT & 30 DAT \\
\hline Nontreated & $0 \mathrm{~d}$ & $0 \mathrm{~b}$ \\
\hline Quinclorac & $2.6 \mathrm{~b}$ & $0.2 \mathrm{~b}$ \\
\hline Bentazon & $0.9 \mathrm{~cd}$ & $0.2 \mathrm{~b}$ \\
\hline Bispyribac-sodium & $6.9 \mathrm{a}$ & $3.8 \mathrm{a}$ \\
\hline Carfentrazone-ethyl & $1.7 \mathrm{bc}$ & $\mathrm{b}$ \\
\hline CV (\%) & 75.57 & 118.80 \\
\hline
\end{tabular}

Means followed by different letters in the column differ by Duncan's test $(\mathrm{p} \leq 0.05)$.
Table 6 - Shoot dry matter at 10,20 and 30 days after the application of treatments (DAT) to rice plants according to nitrogen application time

\begin{tabular}{|l|r|r|c|}
\hline \multirow{2}{*}{$\begin{array}{c}\text { Nitrogen application } \\
\text { time }\end{array}$} & \multicolumn{3}{|c|}{ Shoot dry matter (g) } \\
\cline { 2 - 4 } & 10 DAT & 20 DAT & 30 DAT \\
\hline Without $\mathrm{N}$ & $2.34 \mathrm{~b}$ & $9.29 \mathrm{c}$ & $19.30 \mathrm{~d}$ \\
\hline Before water & $4.36 \mathrm{a}$ & $29.51 \mathrm{a}$ & $63.29 \mathrm{a}$ \\
\hline Half before/Half after & $4.01 \mathrm{a}$ & $22.25 \mathrm{~b}$ & $45.45 \mathrm{~b}$ \\
\hline After water & $2.34 \mathrm{~b}$ & $16.79 \mathrm{~b}$ & $33.70 \mathrm{c}$ \\
\hline CV $(\%)$ & 42.72 & 37.16 & 30.56 \\
\hline
\end{tabular}

Means followed by different letters in the column differ by Duncan's test $(\mathrm{p} \leq 0.05)$. 
was fractionated before and after flooding and $74 \%$ when all nitrogen was applied after flooding. A comparison of application times showed that when $\mathrm{N}$ is applied before flooding at 30 DAT, dry matter accumulation is $39 \%$ higher in comparison to fractioned application, and $87 \%$ higher when $100 \%$ is applied after flooding.

$\mathrm{N}$ application time also resulted in a change in the number of tillers per plant and of empty grains per panicle (Table 7). The lowest tillering was found in the treatment without $\mathrm{N}$ and when all nitrogen was applied after flooding, while the largest number of tillers was found in the treatment with $100 \% \mathrm{~N}$ applied before flooding. The application of urea to water increases the ammoniacal $\mathrm{N}$ content that is subject to losses, since $\mathrm{N}$ is found a few centimeters deep into the soil. As a result, there is less $\mathrm{N}$ available, which decreases the number of tillers, $\mathrm{N}$ uptake and, consequently, dry matter production (Humphreys et al., 1987).

Table 7 - Number of tillers per plant and empty grains per panicle of rice plants according to nitrogen application time

\begin{tabular}{|l|c|c|}
\hline \multicolumn{1}{|c|}{ Nitrogen application time } & Plant tiller $^{-1}$ & Empty grain per panicle \\
\hline Without $\mathrm{N}$ & $6.7 \mathrm{c}$ & $7.9 \mathrm{~b}$ \\
\hline Before flooding & $11.7 \mathrm{a}$ & $8.1 \mathrm{~b}$ \\
\hline Half before/Half after flooding & $9.2 \mathrm{~b}$ & $7.5 \mathrm{~b}$ \\
\hline After flooding & $7.2 \mathrm{c}$ & $10.6 \mathrm{a}$ \\
\hline $\mathrm{CV}(\%)$ & 26.59 & 41.09 \\
\hline
\end{tabular}

Means followed by different letters in the column differ by Duncan's test $(\mathrm{p} \leq 0.05)$.

As for the number of empty grains, it was found that nitrogen applied after flooding resulted in higher sterility (Table 7), possibly because of greater loss of $\mathrm{N}$ and lower utilization by plants, since $\mathrm{N}$ plays an important role in the formation of the reproductive organs and grains of rice (Barbosa Filho, 1987).

The highest productivity was found when quinclorac was applied. It did not differ from the other herbicides and had better performance than the nontreated plants (Table 8). One of the possible explanations for the fact that the nontreated plants had lower productivity may be the application of one herbicide only, cyhalofop-butyl, which is registered to control monocotyledons. Thus, the presence of broadleaf weeds may have competed against rice, interfering with its grain yield. In addition, cyhalofop-butyl, when applied on dry soil, may cause a reduction in control efficiency.

Table 8 - Yield of rice plants which received the application of post-emergence herbicides

\begin{tabular}{|l|c|}
\hline \multicolumn{1}{|c|}{ Herbicide } & Yield $\left(\mathrm{kg} \mathrm{ha}^{-1}\right)$ \\
\hline Nontreated & $7700.3 \mathrm{~b}$ \\
\hline Quinclorac & $9060.7 \mathrm{a}$ \\
\hline Bentazon & $7967.7 \mathrm{ab}$ \\
\hline Bispyribac-sodium & $8315.6 \mathrm{ab}$ \\
\hline Carfentrazone-ethyl & $7901.6 \mathrm{ab}$ \\
\hline CV (\%) & 20.64 \\
\hline
\end{tabular}

Means followed by different letters in the column differ by Duncan's test $(\mathrm{p} \leq 0.05)$. or drained soil followed by irrigation has
provided higher grain yield in studies conducted under different climate and soil conditions (Humphreys et al., 1987). The highest productivity in treatments with nitrogen application was already expected, because $\mathrm{N}$ increases the leaf area of the plant. Therefore, there is increased efficiency in solar radiation interception and photosynthetic rate and, consequently, in grain yield (Fageria and Stone, 2003).

Quinclorac is a hormonal herbicide belonging to the group of synthetic auxins (Roman, 2007). This herbicide is registered to control both barnyard grass and jointvetch (Aeschynomene spp.) in irrigated rice crops, thus it has a higher action spectrum in comparison to other herbicides and results in higher grain yield compared to the nontreated plants.

There was a reduction in thousand grain weight and grain yield when nitrogen was not used or when all nitrogen was applied after flooding (Table 9). The application of $\mathrm{N}$ on dry or drained soil followed by irrigation has rea of the plant. Therefore, there is increased
and in 
Table 9 - Thousand grain weight $(\mathrm{g})$ and yield $\left(\mathrm{kg} \mathrm{ha}^{-1}\right)$ of rice plants according to nitrogen application time

\begin{tabular}{|l|c|c|}
\hline \multicolumn{1}{|c|}{ Nitrogen application time } & Thousand grain weight $(\mathrm{g})$ & Yield $\left(\mathrm{kg} \mathrm{ha}^{-1}\right)$ \\
\hline Without N & $24.17 \mathrm{~b}$ & $6802.8 \mathrm{~b}$ \\
\hline Before flooding & $25.43 \mathrm{a}$ & $9313.7 \mathrm{a}$ \\
\hline Half before/Half after flooding & $25.30 \mathrm{a}$ & $9389.2 \mathrm{a}$ \\
\hline After flooding & $24.40 \mathrm{~b}$ & $7244.7 \mathrm{~b}$ \\
\hline CV $(\%)$ & 2.84 & 15.38 \\
\hline
\end{tabular}

Means followed by different letters in the column differ by Duncan's test $(\mathrm{p} \leq 0.05)$.

The production of rice grains is determined by production components, including number of panicles per area, number of grains per panicle and thousand grain weight (Sui et al., 2013), which are directly influenced by fertilizer supply, mainly N (Feng et al., 2009; Zhang et al., 2013). However, variables such as number of panicles and grain weight may not be related to productivity, due to the lack of uniformity in the stand, light and physical space, making it difficult to measure them and consequently providing high coefficients of variation (Oliveira et al., 2002).

Nitrogen application, in general, results in increased height and dry matter in rice plants; nitrogen application before flooding and the split applications (50\% before and $50 \%$ after flooding) are favorable to the crop. Bispyribac-sodium results in higher injury and reduction of rice plant height, followed by bentazon and carfentrazone-ethyl, while the lowest injury and highest grain yield are due to the application of quinclorac.

\section{REFERENCES}

Andres A., Machado S.L.O. Plantas daninhas em arroz irrigado. In: Gomes A.S., Magalhães Jr. A.M. editors. Arroz irrigado no sul do Brasil. Brasília: Embrapa Informação Tecnológica, 2004. p.457-546.

Barbosa Filho M.P. Nutrição e adubação do arroz: sequeiro e irrigado. Piracicaba: Potafós, 1987

Camargo E.R. et al. Efeito da aplicação de nitrogênio e fungicida no estádio de emborrachamento do arroz na duração e taxa de acúmulo de massa seca dos grãos. Rev Bras Agroci. 2011;17:420-7.

Campestrini R. et al. Eficiência de genótipos de arroz no uso de nitrogênio em solos de terras altas. Pesq Agropec Pernambucana. 2014;19:25-32.

Concenço G. Controle de plantas daninhas em arroz irrigado em função de doses de herbicidas pré-emergentes e início da irrigação. Planta Daninha. 2006;24:303-9.

Duan Y.H. et al. Mechanisms of enhanced rice growth and nitrogen uptake by nitrate. Pedosphere. 2007;17:697-705.

Fageria N.K et al. Growth, yield and yield components of lowland rice as influenced by ammonium sulfate and urea fertilization. $\mathbf{J}$ Plant Nutr. 2011;34:371-86.

Fageria N.K. et al. Nutrient management for improving lowland rice productivity and sustainability. Adv Agron. 2003;80:63-152.

Fageria N.K. et al. Manejo da fertilidade do solo para o arroz irrigado. Santo Antônio de Goiás: Embrapa Arroz e Feijão, 2003. $250 \mathrm{p}$.

Feng L.L. et al. Reduction in SBPase activity by antisense RNA in transgenic rice plants: effect on photosynthesis, growth, and biomass allocation at different nitrogen levels. J Plant Biol. 2009;52:382-94.

Food and Agriculture Organization of the United Nations - FAO. Production and trade statistics. [acessado em: 7 jan. 2015 ]. Disponível em: http:/www.fao.org/economic/ess/ess-trade/en/

Frans R. et al. Experimental design and techniques for measuring and analyzing plant responses to weed control practices. In: Camper, N.D. editor. Research methods in weed science. $3^{\text {rd }}$.ed. Champaign: Southern Weed Science Society, 1986. 37p.

Galon L. et al. Níveis de dano econômico para decisão de controle de capim-arroz (Echinochloa spp.) em arroz irrigado (Oryza sativa). Planta Daninha. 2007;25:709-18. 
Humphreys E. et al. Effects of time of urea application on combine-sown Calrose rice in South-east Australia. I. Crop response and N uptake. Austr J Agric Res. 1987;38:01-112.

Mariot C.H.P. et al. Resposta de duas cultivares de arroz irrigado à densidade de semeadura e adubação nitrogenada. Pesq Agropec Bras. 2003;38:233-41.

Oliveira Jr R.S. et al. Biologia e manejo de plantas daninhas. Curitiba: Ornnipax, 2011. 348p.

Oliveira T.K. et al. Plantas e cobertura e seus efeitos sobre o feijoeiro em plantio direto. Pesq Agropec Bras. 2002;37:1079-87.

Petter F.A. et al. Seletividade de herbicidas inibidores de ALS em diferentes estádios de desenvolvimento do arroz de terras altas.

Pesq Agropec Trop. 2011;41:408-14.

Pinto J.J.O. et al. Controle de capim-arroz (Echinochloa spp.) em função de métodos de manejo na cultura do arroz irrigado.

Planta Daninha. 2008;26:767-77.

Rodrigues B.N., Almeida F.S. Guia de herbicidas. 6a . ed. Londrina: Edição dos Autores, 2011. 697p.

Roman E.S. Como funcionam os herbicidas - da biologia à aplicação. Passo Fundo: Ed Berthier, 2007. 159p.

Sociedade Sul-Brasileira de Arroz Irrigado - SOSBAI. Arroz irrigado: recomendações técnicas da pesquisa para o Sul do Brasil. Gravatal, SC: 2012. 179p.

Sui B. et al. Optimizing nitrogen supply increases rice yield and nitrogen use efficiency by regulating yield formation factors. Field Crops Res. 2013;150:99-107.

Taylaran R. et al. Hydraulic conductance as well as nitrogen accumulation plays a role in the higher rate of leaf photosynthesis of the most productive variety of rice in Japan. J Exper Bot. 2011;62:4067-77.

Vahl L.C., Souza R.O. Aspectos físico-químicos de solos alagados. In: Gomes A.S., Magalhães Jr A.M. organizadores. Arroz irrigado no sul do Brasil. Brasília, DF: Embrapa, 2004. p.97-117.

Wang W.N. Evaluating regional mean optimal nitrogen rates in combination with indigenous nitrogen supply for rice production. Field Crops Res. 2012;137:37-48.

$\mathrm{Xu}$ J.Z. et al. Ammonia volatilization losses from a rice paddy with different irrigation and nitrogen managements. Agric Water Manage. 2012;104:184-92.

Xuejun L., Fusuo Z. Nitrogen fertilizer induced greenhouse gas emissions in China. Curr Opin Environ Sustain. 2011;3:407-13. Zhang Z.J. Mid-season nitrogen application strategies for rice varieties differing in panicle size. Field Crops Res. 2013;150:9-18. 